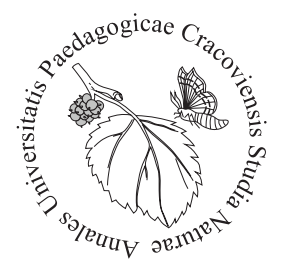

Annales Universitatis Paedagogicae Cracoviensis Studia Naturae, 5: 145-156, 2020, ISSN 2543-8832

DOI: $10.24917 / 25438832.5 .10$

Iveta Marková^, Mikuláš Monoši Department of Fire Engineering, Faculty of Security Engineering, University of Žilina 8215/1, 01026 Žilina, Slovakia; *iveta. markova@fbi.uniza

\title{
Expressions of climatic change in Slovak Republic
}

Introduction

The United Nations Framework Convention on Climate Change (Convention) (SAZ̆P, 1994, 2019a), Kyoto Protocol to the Convention (SAŽP, 1999; Adamišin et al., 2005; Bédi, 2007) and the Paris Agreement (Council EU, 2019) are the International Legal Instrument for the Search for Global Solutions to Climate Change. Slovakia is a party to the above conventions and is obliged to fulfil the resulting obligations. For example, Slovakia has successfully reduced greenhouse gas emissions by $8 \%$ compared to the base year 1990 (SAŽP, 2019a).

Historically, the first universal agreement on climate change - the Paris Agreement, entered into force on 4 November 2016. The aim of the agreement is to limit global temperature growth to a maximum $2^{\circ} \mathrm{C}$ by the end of the century and, if possible, to significantly below $1.5^{\circ} \mathrm{C}$. This document includes reduction commitments not only for developed countries but for all countries that are parties to it. Each country determines for itself how and in which sectors it will make an effort to reduce greenhouse gas emissions. This agreement pays close attention to climate change and enshrines the obligation to prepare for the consequences of these changes. Last but not least, this agreement introduced an obligation to monitor emissions and report on their quantities to all participating countries. Finally, the Paris Agreement was ratified by 181 countries out of a total of 197 parties to the Convention (in terms of developed countries, Russia and Turkey did not ratify this agreement) on 26 October 2018 (SAŽP, 2019a).

The Climate-ADAPT project, led by the European Environment Agency with the support of the United Nations Framework Convention on Climate Change, evaluates the so-called "indicators" of climate change $(E E A, 2019)$. The group of climatic elements includes: greenhouse gas production as concentrations of pollutants, average annual air temperature, annual total atmospheric criteria, drought index and annual soil tem- 
perature (soil index). The selected indicators meet the following criteria: direct or indirect link to the climate system; consistent, homogenised and uninterrupted data over a longer period of time (minimum 30-50 years); guarantee of measuring, monitoring or recording data towards the future and good explanatory value (Mindas et al., 2011).

The aim of this article is to describe the manifestations of climate change in Slovakia (since its inception) according to selected indicators: (1) average annual air temperature, (2) soil temperature, (3) total atmospheric precipitation and (4) drought index over the last decade.

\section{Material and Methods}

On the Slovakian territory, a selection of climate monitoring stations was chosen for the purposes of a representative evaluation of climatic indicators in relation to height above mean sea level (AMSL) (e.g. Bratislava-Airport $4810^{\prime} 12^{\prime \prime} \mathrm{N}, 1712^{\prime} 46^{\prime \prime} \mathrm{E}, \mathrm{AMSL}$ 133 m; Hurbanovo 4752'32" N, 18 11'36" E, AMSL 115 m; Oravská Lesná 49 22'8" N, 19¹1'1" E, AMSL 934 m; Sliač 48 36'43" N, 19²'37" E, AMSL 305 m; Lomnický štít 49 11'45" N, 20 12'46" E, AMSL 2634.4 m; Poprad 49³'34" N, 20¹7'51" E, AMSL 672 m; Košice Airport 4839'47" N, 21 ${ }^{\circ} 14^{\prime} 28^{\prime \prime}$ E, AMSL 230 m; Liptovský Hrádok 49 2'15"N, 19 43'33" E AMSL $637 \mathrm{~m}$ and others) (SHMÚ, 2020a).

Monitoring of climate elements (air temperature, soil temperature, precipitation, air pressure, sunshine duration, number of ice days - maximum temperature lower than $0^{\circ} \mathrm{C}$, number of freezing days - minimum temperature lower than $0^{\circ} \mathrm{C}$, number of summer days - temperature higher than $25^{\circ} \mathrm{C}$, number of tropical days - temperature higher than $30^{\circ} \mathrm{C}$ ) allows for the quantification of climate change. The expression of climatic change is characterised by the chosen study parameters, of which only four were included in this paper (average annual air temperature, soil temperature as a soil dryness index (SDI), total atmospheric precipitation and drought index (DI)).

The soil dryness index (SDI) is determined by the ratio of daily rainfall and the maximum temperature from local meteorological stations for estimating soil dryness, within tens of kilometres. It estimates the millimetres of rain needed to fill the soil with water (Mount, 1980; Jamroz et al., 2014; Hollá, 2016). The current territorial average for total precipitation in Slovakia is calculated in the Slovak Hydrometeorological Institute (SHMÚ) from the monthly totals of 203 stations. This calculation was produced from the approximately 30-100 stations present before 1901 (Lapin, 2020). The drought index (DI) is based on a comparison (ratio) of the annual potential evapotranspiration and the annual total atmospheric precipitation. Alsumaiei (2020) and Paulo et al. (2012) explained identification and testing of the drought index. These indicators began to be monitored gradually. They were first published in the 2010 State of the Environment Report. 
Current data on climatic elements are published annually on the website of the Slovak Environment Agency (SA ̌ZP, 2019b); this data was used in these studies and discussed in terms of the findings and comments of Slovak experts and climatologists.

\section{Results and discussion}

\section{Air temperature}

Climate change is most evident in air temperature, which is confirmed by the readings of this parameter by many hydrometeorological stations. According to previous research, air temperature has been measured in Hurbanovo at a professional level since 1872, with four SHMÚ stations available since 1881, and one in Bratislava since 1851 (Lapin, 2020).

The average territorial deviation of temperature from normal, 1961-1990 ranges, in 2016 was incomparable with the year 2018 . During the two years there was a $1.5^{\circ} \mathrm{C}$ difference in the deviation of the average annual air temperature from the normal 1961-1990 ranges. Concerning means, the average the deviation ranges from $1^{\circ} \mathrm{C}$, $1.0-1.5^{\circ} \mathrm{C}$ and $1.5^{\circ} \mathrm{C}$ in 2016 and in 2018 , and the difference in the deviation of the average annual air temperature from the normal 1961-1990 ranges were increased (Fig. 1). Matejovič and Libo (2020) reported record temperature values. The absolute maximum reached (the highest measured air temperature) was $56.7^{\circ} \mathrm{C}$, Death Valley July 10, 1913, California, USA and in Slovakia: $40.3^{\circ} \mathrm{C}$, Hurbanovo, July 20, 2007. They reported the warmest summer (June-August) was in 2019, with an average air temperature of $23.2^{\circ} \mathrm{C}$ in Hurbanovo. This fact was confirmed by Bartošovičová (2019).

During the period 1881-2016, an average annual air temperature increase of about $1.73^{\circ} \mathrm{C}(S A \check{P} P, 2017 \mathrm{a})$ was observed in Slovakia. The Report on the State of the Environment for 2015 (SAŽP, 2016) states: "warming has been most pronounced in the last twenty years". The year 2016 ended as extremely warm, in comparison with the climatic norm of 1961-1990; 2016 also ended as extremely warm, in comparison with the climatic norm 1961-1990 (SAŽP, 2017a), in most of Slovakia. This characteristic was maintained in the following years (SAŽP, 2018, 2019a)

The number of tropical days has been reported in the State of the Environment Report since 2012 (SAŽP, 2013). The criterion for classifying days as tropical is higher than $30^{\circ} \mathrm{C}$. The normal summer day is day, when the maximum air temperature has increased to at least $25^{\circ} \mathrm{C}$. Based on study data, a growing trend in the number of tropical days was observed in the lowland and uplands of Slovakia (Hurbanovo increased by 20, Liptovský Hrádok increased by 10), for the period 1951-2016 (SAŽP, 2017b). In 2016, 30 tropical days in Hurbanov and 5 days in Liptovský Hrádok were recorded. This was also observed in 2018, where, in both places together, the number of tropical days increased by 16 , compared to the period 1961-1990 (SAŽP, 2019a). An increase 

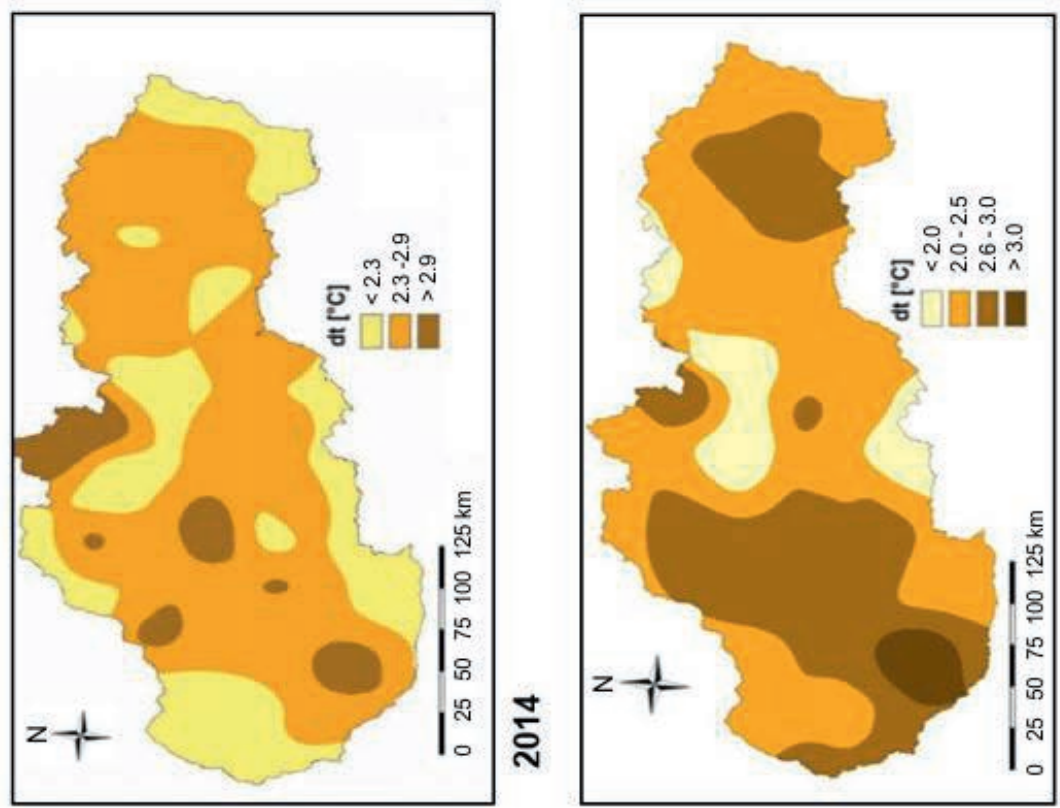

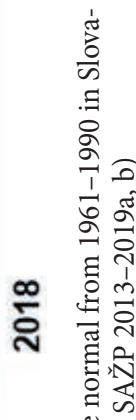
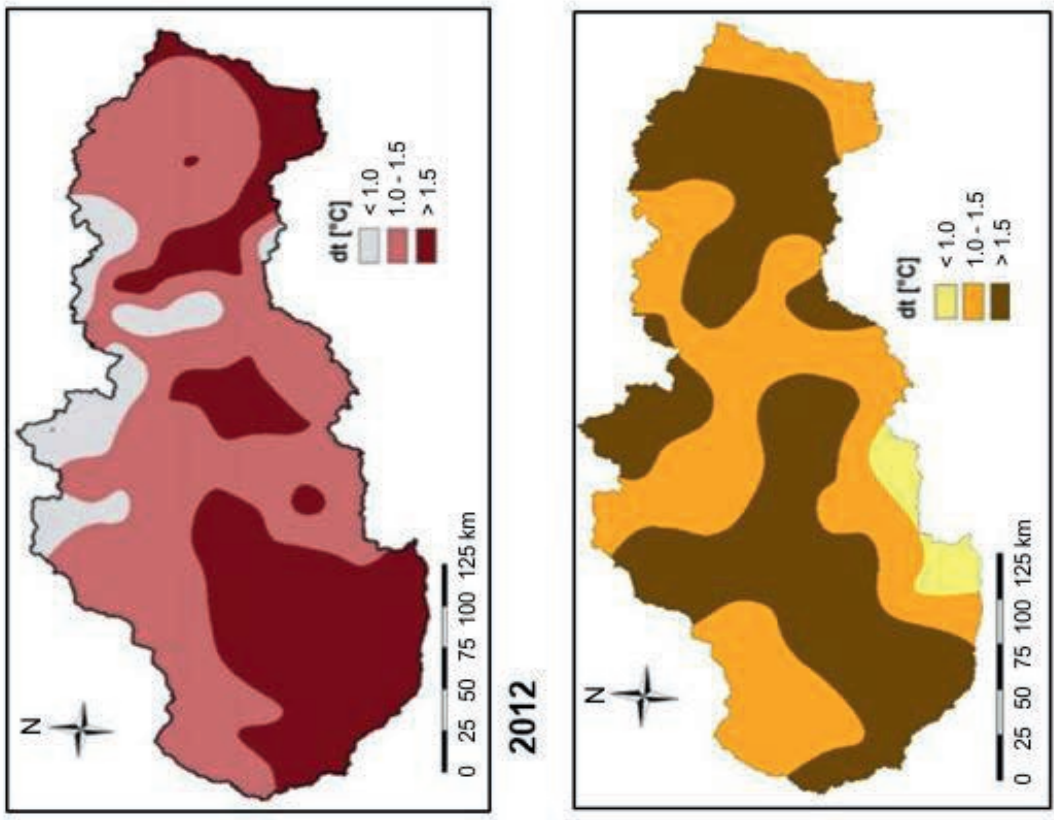

ق

हี Оิ

हैं

焉

可

ํㅗㅇ

亲离

芑 믕

ธ్రా

¿े

유

능

록

을

일

ง

ํㅗㄹ 

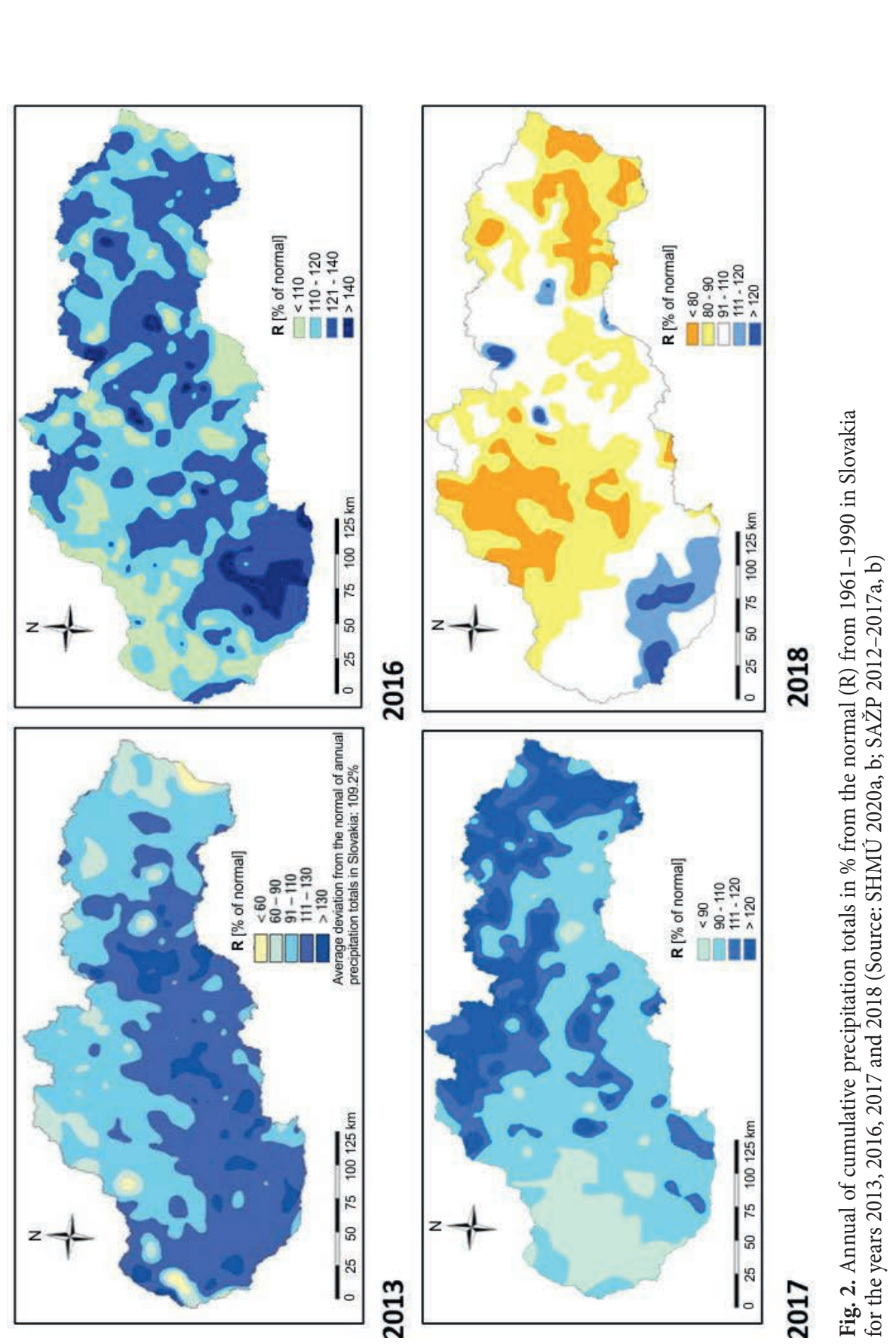

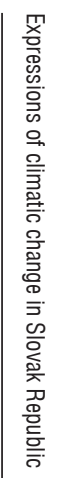


in warm days causes a decrease in the length of the heating season. For example, in Hurbanovo a decrease of 21 days and in Liptovský Hrádok a decrease of 22 days was found during the analysed period (SAŽP, 2017b).

Based on the increase in the number of summer and tropical days, (45 more days compared to the period 1961-1990), the number of ice days, i.e. lower than $0^{\circ} \mathrm{C}$, decreased (a decrease of 12 days compared to the period 1961-1990) (SAZ̆P, 2019a). A detailed explanation of the development of these trends and a forecast of their number through 2090 were reported by Damborská et al. (2006).

In the lowlands throughout Central Europe, due to the frequent alternation of periods with positive and negative average air temperature, snow cover occurrence is irregular (Siman, Slavková, 2019) in winter. The report on the state of the environment for 2016 describes a decrease for all snow cover characteristics (mainly thickness) to a height of $1000 \mathrm{~m}$ in almost the entire territory of the Slovak Republic (an increase was recorded at higher altitudes). In the following years, reports on the state of the environment no longer specify the state of snow cover but only state its decrease.

\section{Soil temperature (soil dryness index)}

Based on this scientific analysis, the soil temperature at a depth of $10 \mathrm{~cm}$ in Hurbanovo was $11.0^{\circ} \mathrm{C}$ and in Liptovský Hrádok was $9.2^{\circ} \mathrm{C}$, in 2016 . A trend of increasing average annual soil temperature at a depth of $10 \mathrm{~cm}$ was observed in lowlands and uplands of Slovakia; in the mountains (Hurbanovo $1.5^{\circ} \mathrm{C}$, Liptovský Hrádok $2.1^{\circ} \mathrm{C}$ ) for the period 1951-2016, the observed temperature increases were more significant (SAŽP, 2018). A drought began to spread first in the northwest, later in the east, of Slovakia in the second half of April 2018. At the beginning of May 2018, there was an extreme drought in $16 \%$ of the territory. The worst situations were in the Žilina, Prešov and Trenčín regions. Extreme drought affected 7.5\% of the country territory in June 2018 (SAŽP, 2019a). This situation caused a deficit of soil moisture and a loss of yields in eastern Slovakia.

\section{Cumulative precipitation totals}

The annual precipitation totals began to be presented in the Reports on the State of the Environment in 2010. The first map presented from 2012 employs a three-colour range with deep blue colours. In 2013, the colour of the map differs significantly and areas are indicated with a significant reduction in percentage cumulative precipitation, less than $60 \%$ of normal. The map from 2015 revealed a declining trend in the annual precipitation totals (Fig. 2) and a decrease in the relative humidity of the air (SAŽP, 2016).

In 2016 (SAŽP, 2017a) there was a decrease in annual precipitation totals of $0.5 \%$, on average, and 2018 precipitation was below normal The upper limit of the percent- 
age range of annual total atmospheric precipitation decreased from $140 \%$ to $120 \%$. At the same time, there were areas with a $60 \%$ deviation from normal in annual precipitation totals during that period (SAŽP, 2019a). The calculation methods for precipitation totals over a selected time period and for scenarios of precipitation totals during extreme precipitation situations in Slovakia are explained by Lapin et al. (2004).

\section{Drought index}

The drought index (Hurbanovo station - 0.22) in the lowland areas of Slovakia revealed an increasing trend for the period 1951-2016. For example, the drought indexes were 1.02 in Hurbanovo and 0.41 in Oravská Lesná in 2016. Detailed statistical highlights are found in the report on the state of the environment for 2016 (MŽP, 2019; SA $\check{Z} P, 2017 \mathrm{a}, \mathrm{b})$. On the other hand, local or widespread drought was much more common than before. This phenomenon was caused mainly by long periods of relatively warm weather with small totals of precipitation in some parts of the growing season. In general, in this part of Europe, the drought phenomenon was associated with relatively warmer winters (no snow cover) and warmer summers (greater evaporation). In some areas of Slovakia, precipitation totals did not deviate from the long-term norms; however, intense, heavy rainfall in summer prevails that results in fast outflow and low water retention. The phenomenon of drought has become part of our lives. In 2018, documents were prepared which took a position and proposed specific measures to be taken to prevent water loss in our environment (Sólymos, 2018); therefore an Action Plan to address the consequences of drought and water scarcity was created (MŽP, 2018; SAŽP, 2018, 2019b).

There is still debate in the scientific literature about which climatic parameters (e.g. precipitation, temperature, evapotranspiration, wind speed, relative humidity, solar radiation, etc.) are the most important in determining the severity of drought. There is general agreement on the importance of precipitation in explaining drought variability and the need to include this variable in the calculation of any drought index (Vicente-Serrano et al., 2009; Jamroz et al., 2014; Tigkas et al., 2014; Amani et al., 2016).

\section{Climate scenarios}

In the third National Report on Climate Change (MŽP, 2001) the climatic scenarios of temperature increase and decrease in annual total precipitation were presented. The calculation was a regional modification of the outputs from two related programs: GCMs (CCCM - the Canadian Centre for Climate Modelling) and GISS (Gaoldard's Institute for Space Studies in the USA). The synthetic data for this topic is presented in table 1 . 
Tab. 1. Scenarios of changes in monthly averages of air temperature $\left[{ }^{\circ} \mathrm{C}\right]$ in 50 -year horizons for the whole of Slovakia in comparison with the normal 1951-1980 (Lapin et al., 1996)

\begin{tabular}{lcccccccccccc}
\hline Horizont & I & II & III & IV & V & VI & VII & VIII & IX & X & XI & XII \\
\hline \multicolumn{8}{c}{ CCCM 1995 (30 year horizons compared to 1995-1980) } \\
\hline 2010 & 1.2 & 1.4 & 1.4 & 1.0 & 0.9 & 0.9 & 1.1 & 1.0 & 1.1 & 1.1 & 0.9 & 0.9 \\
2030 & 2.0 & 2.4 & 2.6 & 1.7 & 1.5 & 1.6 & 1.8 & 1.7 & 1.9 & 1.8 & 1.4 & 1.5 \\
2075 & 3.7 & 4.5 & 4.3 & 3.2 & 2.9 & 3.0 & 3.3 & 3.2 & 3.6 & 3.4 & 2.7 & 2.8 \\
\hline \multicolumn{7}{c}{ CCCM } & 1995 & (50 year horizons compared to & $1995-1980$ from the modification for 1901-1990) \\
\hline 2010 & 0.5 & 0.7 & 0.9 & 0.7 & 0.4 & 0.6 & 0.9 & 1.0 & 1.0 & 0.9 & 0.6 & 0.4 \\
2030 & 0.9 & 1.2 & 1.4 & 1.1 & 0.8 & 1.1 & 1.4 & 1.5 & 1.6 & 1.2 & 0.7 & 0.7 \\
2075 & 2.2 & 2.9 & 2.8 & 2.3 & 2.3 & 2.9 & 3.4 & 3.6 & 3.6 & 3.0 & 2.0 & 1.0 \\
\hline
\end{tabular}

CCCM - Canadian Centre for Climate Modelling

From 1993, the Report has developed and presented a series of different climate scenarios for Slovakia through the year 2100. These scenarios are now being evaluated through comparison with the actually recorded weather measurements (Lapin et al., 1996, 2000).

Tab. 2. Comparison of climatic elements as average deviations from the normal 1961-1990, based on the Reports on the state of the environment prepared by the Slovak Environment Agency in the years 2012 to 2018 (SAŽP, 2012-2019a, b)

\begin{tabular}{lccccccc}
\hline Climate element & 2012 & 2013 & 2014 & 2015 & 2016 & 2017 & 2018 \\
\hline $\begin{array}{l}\text { average air temperature deviation } \\
\begin{array}{l}\Delta \mathrm{T}\left[{ }^{\circ} \mathrm{C}\right] \\
\text { of cumulative precitipation totals }\end{array}\end{array}$ & 1.3 & 1.3 & 2.4 & 2.1 & 1.5 & 1.3 & 2.4 \\
\begin{tabular}{l} 
on Slovakia [\%] \\
\hline
\end{tabular} & 95.3 & 109.2 & $\mathrm{X}$ & 93.0 & 119.8 & 106.5 & $\mathrm{X}$ \\
\hline
\end{tabular}

$\mathrm{X}$ - not mentioned in the report

By 2011 it was already clear that the forecasted goal of limiting the increase in global temperature to a maximum of $2^{\circ} \mathrm{C}$ by the end of the century was unrealistic (SHMÚ, 2020a,b). At present, the growth trend is on average $1^{\circ} \mathrm{C}$ in a 100 -year average. The described 2011 analysis already forecasts the stated goal will be surpassed in 2075. The real data from Slovakia from 2012, for comparison (Tab. 2), shows the difference as the average deviation of air temperature DT (increase) and total annual precipitation in Slovakia as the \% of normal, from the years 1961-1990 (decrease) (SAZ̆P, 2012-2019a, b).

The consequences of developing climate system changes are visible in the reactions of flora and fauna. Changing conditions, due to the effects of greenhouse gases, such as carbon dioxide concentration, increase the average air temperatures or reduce water availability thereby affecting the life cycle of plants and animals. In phenological phases, expressions of the life cycle of plants and animals, certain destabilising tendencies were registered, which may be related to the complex climatic-natural conditions in Slovakia. Changes in animal distribution areas as well as in changes in their behaviour 
were also significant (SA ̌̌P, 2016). Changes in the structure and composition of habitats and an exchange of species in the habitats have been observed. These factors will reduce the resilience of ecosystems, reduce their ability to provide ecosystem services or cause ecosystem disintegration (SAŽP, 2019a).

\section{Conclusion}

Slovakia, during the years 1881-2018, underwent significant changes in all monitored climatic elements, e.g.: (1) an increase in the average cumulative air temperature by approximately $1.73^{\circ} \mathrm{C},(2)$ a decrease in cumulative atmospheric precipitation totals by on average $0.5 \%$ (in the some parts of south Slovakia the decrease was even greater than $10 \%$, in the north and northeast it rarely increased to $3 \%$ ) and (3) a decrease in soil moisture and an increase in the drought index. If we accept these changes, we must also accept the emergence of new adverse events, such as droughts, forest fires, floods and torrential rains, for which rescue equipment must be prepared.

Acknowledgements

This work was supported by the Slovak Education Agency 014UKF-4/2020.

\section{Conflict of interest}

The authors declare no conflict of interest related to this article.

\section{References}

Adamišin, P., Andrejovský, P., Huttmanová E. (2005). Kjótsky protokol ako možný zdroj regionálnych disparít. Acta regionalica et Environmentalistica (The Kjótsky Protocol as a possible source of regional disparities. Regional and Environmental Act). [In Slovak]

Alsumaiei, A.A. (2020). Monitoring hydrometeorological droughts using a simplified precipitation index. Climate, 8, 19. https://doi.org/10.3390/cli8020019

Amani, M., Salehi, B.,Mahdavi, S., Masjedi, A., Dehnavi, S. (2016). Temperature-vegetation-soil moisture dryness index (TVMDI). Remote Sensing of Environment, 197, 1-14. https://doi.org/10.1016/j. rse.2017.05.026

Bartošovičová, M. (2019). Mimoriadne až extrémne prejavy počasia na Slovensku a čo od neho ešte môžeme očakávat? Vedy o Zemi a environmentálne vedy (Extraordinary to extreme weather events in Slovakia and what else can we expect from it? Earth sciences and environmental sciences). https:// vedanadosah.cvtisr.sk/mimoriadne-az-extremne-prejavy-pocasia-na-slovensku-a-co-od-neho-estemozeme-ocakavat [In Slovak]

Bédi, E. (2007). Klimatické zmeny - vedecké a politické aspekty. Aktuálne témy v oblasti klimatických zmien a obnovitelných zdrojov energie (prezentácia) 28.11.2007, Junior Hotel, Bratislava (Climate change - scientific and political aspects. Current topics in the field of climate change and renewable energy sources (presentation) 28.11.2007, Junior Hotel, Bratislava). http://www.inforse.org/europe/ fae/Inforse Seminar - klima 28.11.2007.ppt [In Slovak]

Damborská, I., Lapin, M., Melo, M. (2006). Možné zmeny počtu dní s charakteristickými dennými priemermi teploty vzduchu a dennými úhrnmi zrážok na Slovensku do roku 2090 (Possible changes in the number of days with characteristic daily averages of air temperature and daily total precipitation in Slovakia until 2090). In: J. Rožnovský, T. Litschmann, I. Vyskot (eds.), Fenologická odezva proměn- 
livosti podnebí, Brno 22.3.2006. http://www.cbks.cz/sborník06/prispevky/DamborskaLapinMelo.pdf [In Slovak]

EEA - European Environment Agency (2019). Indicators: Climate adapt. https://climate-adapt.eea.europa.eu/ Hollá, K. (2016). Results of survey among SEVESO establishments in the Slovak Republic. Journal of Chemical Health \& Safety, 23(2), 9-17.

Jamroz, E., Weber, J., Debicka, M. (2014). Trophic soil index of the rusty soils affected by clear-cutting in the Spala Forest District. Sylwan, 158(9), 669-674.

Lapin, M. (2020). Aktuálne zmeny teploty na Slovensku (Current temperature changes in Slovakia). https://milanlapin.estranky.sk/clanky/aktualne-zmeny-teploty-na-slovensku/ [In Slovak]

Lapin, M., Melo, M., Damborská, I., Gera, M. (2004). Scenáre úhrnov zrážok za vybrané časové obdobie a tvorbu scenárov úhrnov zrážok počas extrémnych zrážkových situácií na Slovensku (Scenarios of precipitation totals for a selected time period and creation of scenarios of precipitation totals during extreme precipitation situations in Slovakia). In: J. Rožnovský, T. Litschmann (eds.), Seminár „Extrémy počasí a podnebí, Brno, 11. března . http://www.cbks.cz/sbornik04/prispevky/LAPIN1.pdf [In Slovak]

Lapin, M., Melo, M., Damborská, I., Gera, M., Faško, P. (2000). Nové scénare klimatickej zmeny pre Slovensko na báze výstupov prepojených modelov všeobecnej cirkulácie atmosféry (New climate change scenarios for Slovakia based on the outputs of interconnected models of general atmospheric circulation). In: Národný klimatický program SR, 5(8). Bratislava: MŽP SR, SHMÚ, p. 5-34. [In Slovak]

Lapin, M., Závodský, D., Majerčáková, O., Mindáś, J., Špánik, F. (1996). Preliminary results of volunerability and adaptation assessment for Slovakia. In: Vulnerability and adaptabilition to climate change. U.S. Countries Studies Program. Dordrecht, Boston, London: Kluver Academic Publisher, p. 295-312.

Matejovič, P., Libo, M. (2020). Rekordné hodnoty meteorologických prvkov vo svete a na Slovensku (Record values of meteorological elements in the world and in Slovakia). http://nun.sk/rekordy.html [In Slovak]

Mindaš, J., Páleník, V., Nejedlík, P. (2011). Dôsledky klimatickej zmeny a možné adaptačné opatrenia v jednotlivých sektoroch (Consequences of climate change and possible adaptation measures in individual sectors). Záverečná správa. EFRA - Vedecká agentúra pre ekológiu a lesníctvo, Zvolen, Bratislava, November 2011, 252 s. [In Slovak]

Mount, A.B. (1980). Estimation of evaporative losses from forests: A pro ven simple model with wide applications. Paper to Hydrology and Water Resources Symposium 1980, Adelaide, 4-6 Nov. 1980, Preprints of Papers, Inst. Eng. Aust., p. 101-105.

MŽP - Ministerstvo životného prostredia SR (Ministry of the Environment of the Slovak Republic) (2001). Tretia Národná správa o zmene klímy. Ministerstvo životného prostredia SR, Bratislava,. p. 24. https://lnk.sk/axMQ_In Slovak]

MŽP - Ministerstvo životného prostredia SR (Ministry of the Environment of the Slovak Republic) (2018). $\mathrm{H}_{2} \mathrm{O}$ dnota je voda - Akčný plán na riešenie dôsledkov sucha a nedostatku vody. https://www.minzp. sk/files/sekcia-vod/hodnota-je-voda/h2odnota-je-voda-akcny-plan-riesenie-dosledkov-sucha-nedostatku-vody.pdf [In Slovak]

MŽP - Ministerstvo životného prostredia SR (Ministry of the Environment of the Slovak Republic) (2019). Implementácia smernice Európskeho parlamentu a Rady 2007/60/ES z 23. októbra 2007 o hodnotení a manažmente povodňových rizík „Predbežné hodnotenie povodňového rizika v Slovenskej republike - aktualizácia 2018. https://www.minzp.sk/files/sekcia-vod/hodnotenie-rizika-2018/ phpr_sr2018.pdf [In Slovak]

Paulo, A.A., Rosa, R.D., Pereira, L.S. (2012). Climate trends and behaviour of drought indices based on precipitation and evapotranspiration in Portugal. Natural Hazards and Earth System Sciences, 12, 1481-1491. https://doi.org/10.5194/nhess-12-1481-2012 
Council EU - Rada Európskej únie (Council of the European Union) (2019). Parižska dohoda o zmene klimy (Paris Agreement on Climate Change). https://www.consilium.europa.eu/sk/policies/climate-change/paris-agreement/ [In Slovak]

SAŽP - Slovenská Agentúra Životného Prostredia (Slovak Environment Agency) (1994). Rámcový dohovor o zmene klímy (Framework Convention on Climate Change). https://www.enviroportal.sk/ dokumenty/medzinarodne-dohovory/dohovor/1? [In Slovak]

SAŽP - Slovenská Agentúra Životného Prostredia (Slovak Environment Agency) (1999). (Kyoto Protocol to the United Nations Framework Convention on Climate Change). https://www.enviroportal.sk/ dokumenty/medzinarodne-dohovory/dohovor/2_[In Slovak]

SAŽP - Slovenská Agentúra Životného Prostredia (Slovak Environment Agency) (2012). Výročná správa stavu životného prostredia na Slovensku 2011. https://www.enviroportal.sk/uploads/report/2011-sprava.pdf [In Slovak]

SAŽP - Slovenská Agentúra Životného Prostredia (Slovak Environment Agency) (2013). Výročná správa stavu životného prostredia na Slovensku 2012. Čast “Zmeny klímy”. https://www.enviroportal.sk/uploads/report/2012-04-3-klimat.pdf [In Slovak]

SAŽP - Slovenská Agentúra Životného Prostredia (Slovak Environment Agency) (2014). Výročná správa stavu životného prostredia na Slovensku 2013. Čast “Zmeny klímy”. https://www.enviroportal.sk/uploads/report/2013-sprava-o-stave-zp.pdf [In Slovak]

SAŽP - Slovenská Agentúra Životného Prostredia (Slovak Environment Agency) (2015). Výročná správa stavu životného prostredia na Slovensku 2014. Čast' “Zmeny klímy”. https://www.enviroportal.sk/uploads/report/2014-05-4-zmena-klimy.pdf [In Slovak]

SAŽP - Slovenská Agentúra Životného Prostredia (Slovak Environment Agency) (2016). Výročná správa stavu životného prostredia na Slovensku 2015. Čast “Zmeny klímy”. https://www.enviroportal.sk/uploads/report/zmena-klimy.pdf [In Slovak]

SAŽP - Slovenská Agentúra Životného Prostredia (Slovak Environment Agency) (2017a). Výročná správa stavu životného prostredia na Slovensku 2016. Čast "Zmeny klímy". http://enviroportal.sk/spravy/ detail/7043? $=6961$ _[n Slovak]

SAŽP - Slovenská Agentúra Životného Prostredia (Slovak Environment Agency) (2017b). Výročná správa stavu životného prostredia na Slovensku 2016. https://www.enviroportal.sk/spravy/detail/8142 [In Slovak]

SAŽP - Slovenská Agentúra Životného Prostredia (Slovak Environment Agency) (2018). Výročná správa stavu životného prostredia na Slovensku 2017. Čast' “Zmeny klímy”. https://www.enviroportal.sk/ spravy/detail/10282?p=9341 [In Slovak]

SAŽP - Slovenská Agentúra Životného Prostredia (Slovak Environment Agency) (2019a). Výročná správa stavu životného prostredia na Slovensku 2018. Čast "Zmeny klímy" (Anual report about environment, Part: Climatic Change). https://www.enviroportal.sk/uploads/report/10282.pdf [In Slovak]

SAŽP - Slovenská Agentúra Životného Prostredia (Slovak Environment Agency) (2019b). Správy o stave životného prostredia. Retrieved Marec, 2018, from: https://www.enviroportal.sk/spravy/kat21? [In Slovak]

SHMÚ - Slovenský hydrometeorologický ústav (Slovak Hydrometeorological Institute) (2020a). Scenare budúcej klímy. http://www.shmu.sk/sk/?page=1069\#! [In Slovak]

SHMÚ - Slovenský hydrometeorologický ústav (Slovak Hydrometeorological Institute) (2020b). Primerná mesačná teplota na Slovensku. http://www.shmu.sk/sk/?page=1610\&id_[In Slovak]

Siman, C., Slavková, J. (2019). Vývoj snehovej pokrývky na Slovensku v období rokov 1981/1982 2017/2018 (Development of snow cover in Slovakia in the period 1981/1982 - 2017/ 2018). Bratislava: SHMÚ. http://www.shmu.sk/File/KMO/SimanC_SlavkovaJ_Vyvoj_snehovej_pokryvky_Slovensku_obdobie1981_82_2017_18.pdf [In Slovak] 
Sólymos, L. (2018). Investície do opatrení proti suchu a nedostatku vody pomôžu zlepšit životné prostredie, ale aj kvalitu života ludí (Investing in measures to combat drought and water scarcity will help to improve the environment, but also the quality of people's lives). https://www.minzp.sk/tlacovy-servis/tlacove-spravy/tlacove-spravy-2018/tlacove-spravy-marec-2018/solymos-investicie-do-opatreni-proti-suchu-nedostatku-vody-pomozu-zlepsit-zivotne-prostredie-aj-kvalitu-zivota-ludi.html [In Slovak]

Tigkas, D., Vangelis, H., Tsakiris, G. (2014). The drought indices calculator (DrinC). Proceedings of $8^{\text {th }}$ International Conference of EWRA, $26^{\text {th }}-29^{\text {th }}$ June 2013, Porto, Portugal.

Vicente-Serrano, S.M., Begueri, S., Lopéz-Moreno, J.I. (2009). A multiscalar drought index sensitive to global warming: The standardized precipitation evapotranspiration index. Journal of Climate, 23, 1696-1718. https://doi.org/10.1175/2009JCLI2909.1

Abstract

The development of climate change is evaluated on the basis of trends in a long-term time series (19512018) of individual climatic elements by comparing values from individual years with the normal period in climatology of 1961-1990. The aim of the article is to present the manifestations of climate change in Slovakia (since its inception) according to selected indicators: (1) average annual air temperature, (2) soil temperature, (3) total atmospheric precipitation and (4) drought index over the last decade. The data presented in the article were obtained from public reports on the state of the environment in the Slovakia and other related documents. Slovakia, during the years 1881-2018, underwent significant changes in all monitored climatic elements. The most significant changes were in 2017 and 2018.

Key words: annual air temperature, annual total precipitation, climate change, dryness index

Received: [2020.06.08]

Accepted: [2020.09.13]

\section{Ekspresja zmian klimatu w Republice Słowackiej Streszczenie}

Postęp zmian klimatu ocenia się na podstawie trendów w długoterminowych szeregach czasowych (19512018) poszczególnych elementów klimatu, na podstawie porównania wartości z wielu lat, z normalnym okresem w klimatologii 1961-1990. Celem artykułu jest przedstawienie przejawów zmian klimatycznych na Słowacji (od ich powstania) według wybranych wskaźników: (1) średnia roczna temperatura powietrza, (2) temperatura gleby, (3) suma opadów atmosferycznych, (4) susza indeks w ciągu ostatniej dekady. Dane przedstawione $\mathrm{w}$ artykule pochodzą z publicznych raportów na temat stanu środowiska w Republice Słowackiej i innych powiązanych dokumentów. W Słowacji w latach 1881-2018 znaczącym zmianom uległy wszystkie monitorowane elementy klimatyczne. Największe zmiany zaobserwowano w latach 2017 i 2018.

Słowa kluczowe: roczna temperatura powietrza, roczne sumy opadów, zmiany klimatu, wskaźnik suszy

\section{Information on the authors}

Iveta Marková https://orcid.org/0000-0001-9424-2024

She deals with simulate accidents (mainly fires) with the purpose of creation of experimental research database, creation of simulations and animations of chosen crises models for all first respondents (fire scenarios, evacuation models), on-site experimental monitoring activities (temperature, microclimatic conditions, flames) and fire experiments.

\section{Mikuláš Monoši}

He deals with firefighting technics using by the Fire and Rescue Corps in the Slovak Republic. The importance of a criterion assessment of firefighting technics, climate changes and forest fires in the Slovak Republic. 